\title{
FREEDOM OF SERVICES BY CORRESPONDENCE AS THE “FIFTH FREEDOM” FOR THE DIGITAL SINGLE MARKET - LIMITATIONS BY THE TFEU
}

\author{
Zlatan Meškić, PhD, Associate Professor \\ University of Zenica \\ Fakultetska bb, 72000 Zenica \\ zmeskic@prf.unze.ba
}

\begin{abstract}
The freedom of services by correspondence should be one of the most important market freedoms in the EU legislative politics and the CJEU jurisprudence. The announcement of the establishment of a fifth market freedom on data flow is directly addressed by the freedom of services by correspondence. The growing importance of the freedom of services in general is in line with the rise of the EU service sector as the main contributor to growth and employment in the EU, accounting for about two thirds of both EU employment and value added. In addition, since 2015 the Digital Single Market is one of European Commission's political priority that aims at providing free access to online services. Online services are in most part services by correspondence, where neither provider nor recipient travels cross border. The truth is that the freedom of services by correspondence is barely ever mentioned explicitly neither by EU legislator nor by the CJEU. The EU legislator has rather chosen a sectoral approach to the Digital Single Market, fragmenting the fifth market freedom to several narrow pieces of legislation. The paper deals with the question why the freedom of services by correspondence has not acquired the same position as the freedom of goods. The analysis will focus on answering this question on the grounds of the theory of convergence of market freedoms and its limits.
\end{abstract}

Keywords: freedom of services by correspondence; digital service; Digital Single Market; geoblocking

\section{INTRODUCTION}

In the digital era, when the intangible goods cross the border without the service provider or customer moving away from their computer or smartphone, it is the freedom of services by correspondence which is most suitable to take the leading role in abolishing restrictions to the access of online goods and services. The EU Digital Single Market strategy of $2015^{1}$ confirms that it will be foremost the role of the freedom of services and to some extent the freedom of establishment, to

European Commission, Communication from the Commission to the European Parliament, the Council, the European Economic and Social Committee and the Committee of the Regions - A Digital Single Market Strategy for Europe, COM(2015) 192 final 
fulfill the set goal. At the same time, this strategy does not mention the services by correspondence even once by its name. On the contrary, the Digital Single Market Strategy has contributed to a great activity of EU legislator and that is why secondary law took over the primary role in the application of market freedoms to digital content. In addition, the EU Parliament advertised that the free flow of non-personal data regulated by the Free Flow of Non-Personal Data Regulation ${ }^{2}$ shall become the fifth freedom of the EU Internal Market" ${ }^{3}$. The title of the "fifth market freedom" is misleading. Firstly, the question arises if we do not already have four, five or six freedoms, considering that the freedom of persons consists of the freedom of workers (Art. 45 TFEU) and the freedom of establishment (Art. 49 TFEU) and the freedom of payment has an independent scope of application from the freedom of payment ${ }^{4}$. Secondly, the free flow of non-personal data clearly falls within the scope of application of the freedom of services by correspondence, as the digital (non-tangible) content crosses borders without movement of the service provider or recipient, as will be discussed in the paper. Insofar, the Free Flow of Non-Personal Data Regulation may only regulate in more precise manner what is already understood by the freedom of services by correspondence. As will be further elaborated, Non-Personal Data Regulation does not go beyond the level of protection already guaranteed by the freedom of services by correspondence. The term "fifth freedom" should be rather understood as a justified emphasize of the importance of the digital content on the EU market today. The use of the term does not have any legal consequences and surely does not create any "new" market freedom. Its aim is to give a new name to existing freedoms or an important part of one freedom. The focus of this analysis will be the question if the freedom of services by correspondence is capable of taking a more important role in the digital era, considering the limitations by the TFEU. The analysis of the content of the Digital Single Market only serves the purpose of analyzing the TFEU limitations of the provision of services by correspondence and does not have an independent purpose. The developments in the EU legislation within the Digital Single Market strategy since its adoption in 2015 will be taken into account. A comparison to the freedom of tangible goods as a possible convergent market freedom to the services provided by correspondence will be made. Considering that the freedom

2 Regulation (EU) 2018/1807 on a framework for the free flow of non-personal data in the European Union, [2018] OJ L 303/59

3 European Parliament, "Free flow of non-personal data: Parliament approves EU's fifth freedom" [http://www.europarl.europa.eu/news/en/press-room/20180926IPR14403/free-flow-of-non-personal-data-parliament-approves-eu-s-fifth-freedom] Accessed 11.05.2019

4 Barnard C., The Substantive Law of the EU-the Four Freedoms, Oxford 2016, p. 521; Gramlich L., Freier Kapital - und Zahlungsverkehr, in Pechstein M.; Nowak C., Häde U. (eds.), Frankfurter Kommentar, Frankfurt 2017, 1042 
of services by correspondence is not directly regulated by Art 56 and 57 TFEU, there is a lack of clarity in regard to its scope of application and its application to non-discriminatory market restrictions. The need for interpretation by the CJEU is much greater than with regards to the active or passive freedom of services.

When analyzing the freedom of services by correspondence in light of the Digital Single Market, the common structure of the market freedoms will be used: scope of application, discrimination/restriction and justifications. Therefore, this analysis is conducted under the premise of the theory of convergence of market freedoms. Arguments in favor or against convergence and divergence of market freedoms will not be discussed, because this has already been done elsewhere. ${ }^{5}$ In general, the analysis will show that the potential "fifth market freedom" is unnecessarily narrowed down to the free flow of non-personal data by EU secondary law or the understanding thereof. Contrary to the main division emphasized by the EU Parliament and also followed by the EU legislator in general, to personal and non-personal data, it is clear that both economically and legally both personal and non-personal data need to be a part of a "fifth freedom of the EU internal market". From the internal market law perspective personal data enjoy insofar a special status as they are under the scope of application of the fundamental right to privacy under Art 8 ECHR or even as a special fundamental right to personal data protection under Art 8 Charter of Fundamental Rights, which need to be taken into account a part of the justification of limitations to the free data flow. Accordingly, this will be presented under the subchapter of justifications of market restrictions. However, personal data are thereby not excluded from market freedoms. Fundamental rights have in the jurisprudence of the CJEU served as both limitations to market freedoms $s^{6}$, but also for widening the scope of application of market freedoms ${ }^{7}$. One of the points to be proven by this analysis is that the free flow of digital goods should profit from the convergence of the market freedoms and great development of the market freedoms by the CJEU jurisprudence. This is foremost related to the freedom of goods, as it one of the ideas of this paper to put into question to which extent digital goods should be distinguished in their treatment within the internal market in comparison to tangible goods covered by the freedom of goods. Namely, the current secondary legislation adopted within the Digital Single Market, is mostly limited to the prohibition of (direct and indi-

\footnotetext{
$5 \quad$ Kingreen Th., Die Struktur der Grundfreiheiten des Europäischen Gemeinschaftsrechts, Berlin 1999; Trstenjak V.; Beysen E., Das Prinzip der Verhältnismäßigkeit in der Unionsrechtsordnung, Zeitschrift für Europarecht, Vol. 45, 2012, pp. 265-284, 275

6 CJEU, Eugen Schmidberger, Internationale Transporte und Planzüge v. Austria [2003], C-112/00, I-5659, par. 82

CJEU, Commission v. France, C-265/95, [1997], I-6959
} 
rect) discrimination and does not extend to non-discriminatory restrictions. This is surprising considering that a better access to online goods and services, as one of the goals of this strategy, will hardly be accomplished without encompassing unjustified non-discriminatory restrictive measures. Even the prohibition of geoblocking, where the discriminatory nature of the measures is most visible, would not be solved in the long run just by prohibiting discrimination, as geographical restrictions may be executed through many non-discriminatory means. ${ }^{8}$ Again, such non-discriminatory measures would be prohibited by primary law, within the jurisprudence of the CJEU on the freedom of services. A more detailed analysis on this question will be conducted in the subchapter on discrimination and non-discriminatory measures.

The paper is divided into three parts. Firstly, it will be established what the understanding of the freedom of services by correspondence is under the TFEU as interpreted and developed further by the CJEU; secondly, in light of the market freedom structure what element of the scope of application, discrimination/restriction and justification have now been regulated within the Digital Single Market and how; and thirdly what is the conclusion so far on the contribution of the secondary legislation to the EU digital single market and its relationship to the freedoms of services by correspondence.

\section{FREEDOM OF SERVICES BY CORRESPONDENCE AS A MODALITY OF THE FREEDOM OF SERVICES}

The freedom of services today is far beyond what the fathers of the Treaties had in their mind when drafting the articles on the free movement of service in 59-66 of the EEC. Although this statement is very true for every market freedom, it was only with regards to the freedom of services that several modalities of the market freedom have been developed. The modalities do not only apply to the restrictions of the home or host state, but rather also to the other party to the contract, the recipient of the service or the service itself. The original intent of the Treaty makers was to prevent restrictions to the service provider when providing services in another Member State. It was not before the CJEU in 1984 in Luisi and Carbone held that freedom of services includes the "passive freedom of services", that such modality of the freedom of services was acknowledged. The wider interpretation

\footnotetext{
8 Schmidt-Kessen M.J., EU Digital Single Market Strategy, Digital Content and Geo-Blocking: Costs and Benefits of Partitioning EU's Internal Market, Columbia Journal of European Law, Vol. 24, 2018, p. 561-576, 570

9 CJEU, Graziana Luisi and Giuseppe Carbone v Ministero del Tesoro, Joined cases 286/82 and 26/83, [1984] ECR 377, par. 16.
} 
of Art 59 EEC meant that the recipient of services also enjoys the right not to be restricted when receiving the service in another Member State. Later the passive freedom of services and the corresponding jurisprudence became the driving force behind the development towards the EU citizenship.

Interestingly, the freedom of services by correspondence was established much earlier by the CJEU. Already in 1974 the CJEU held in Sacchi ${ }^{10}$ that a television signal by its nature falls under the freedom of services, although in the case at hand naturally neither the provider nor the recipient of the service where crossing the border. The classis fields of application of this freedom was initially related to the media (radio and television), and later to the banking and insurance sector. ${ }^{11}$ With the progress of digitalization, it was only easy to assume that the freedom of services by correspondence will become even more important, if not the most important freedom in the digital era. It needs to be examined if the provisions of the TFEU allow for such development.

\section{FREEDOM OF SERVICES BY CORRESPONDENCE UNDER THE TFEU}

The freedom of services by correspondence is not defined by primary law of the $\mathrm{EU}$ and therefore also the criteria for its scope of application is not clear. It is derived from the criteria for the scope of application of the active and passive freedom of services. Therefore, first the criteria for the application of the active and passive freedom of services needs to be discussed in order to establish the scope of application of the freedom of services by correspondence. It is the position of this paper that the lack of clear definition of the freedom of services by correspondence in the EU primary law and the lack of clarifying jurisprudence by the CJEU is one of the reasons that the freedom of services by correspondence did not take the expected role of the fifth freedom for the Digital Single Market.

\subsection{Service}

The term "service" is an autonomous EU term defined by the elements contained in Art 56 and 57 of the TFEU. The cross-border requirement can be taken out of Art 56 TFEU, while Art 57 TFEU clearly requires a remuneration for the service provided. In addition, the Art $57 \mathrm{TFEU}$ sets the criteria of the temporariness and pursue of the activity where some examples of the business activity can also be found. The other elements of the service definition arise out of the differences

\footnotetext{
10 CJEU, Giuseppe Sacchi, 155-73, [1974] ECR 409, par. 6

11 Oppermann Th.; Classen C. D.; Nettesheim M., Europarecht, München 2009, p. 467
} 
between services and other market freedoms, and these are the "intangibility" of the service in distinction from tangibility of the goods, and the service provider as a self-employed person in distinction to the freedom of workers. By taking into account all of the abovementioned elements, a "service" within the meaning of the freedom of services means a intangible service provided within a self-employed activity temporarily pursued for renumeration on the territory of another Member State. ${ }^{12}$

\subsection{Personal scope of application}

The freedom of services is exclusively reserved for the nationals of a Member State. The legislator of the EU may in accordance with Art 56 (2) TFEU widen the personal scope of application with the acts of secondary law but did not do so thus far. Differently than with regards to the freedom of workers and the primary (but not the secondary) establishment, the personal scope of application requires not only the nationality of a Member State of the service provider, but also that he is established on the territory of another Member State. In accordance with Art 56 (1) TFEU the provider and recipient of the services need to be established in different Member States.

Here a difference between the active and the passive freedom of services needs to be made. The active freedom of services requires that the service provider, as the holder of the rights from this freedom, needs to be a national of one Member State with his establishment on the territory of the EU. His contractual partner, the recipient of the service, needs to have an establishment on the EU territory as well, but does not need to have nationality of the EU. ${ }^{13}$ Therefore the cross-border element is exclusively defined over the criteria of "establishment" in another Member State. ${ }^{14}$

The situation covered by the passive freedom of services causes more uncertainty. It is clear that the recipient of the services which, as a holder of the rights, relies on the freedom of services, needs to have the citizenship of the Union. Although there are contrary opinions in the literature, the recipient of the service in addition needs to have establishment on the territory of the EU, because otherwise there is no cross-border element within the EU. ${ }^{15}$ At the same time there is consent that

\footnotetext{
12 Haratsch A.; Koenig Ch.; Pechstein M., Europarecht, Tübingen 2010, p. 452

13 Holoubek M., in: Schwarze J. (ed.), EU-Kommentar, Baden Baden 2009, Art. 49/50 EGV, par. 49

14 Bordaš B., in: Etinski R. et al. (eds.), Osnovi Prava Evropske unije, Novi Sad 2010, p. 298

15 Randelzhofer A.; Forsthoff U., in: Grabitz E.; Hilf M. (eds.), Das Recht der Europäischen Union-Kommentar, München 2009, Art. 49/50 EGV, par. 25; Haratsch; Koenig; Pechstein, op. cit., note 12, p. 457; Opposite view in Rolshoven M., „Beschränkungen“ des freien Dienstleistungsverkehrs, Berlin 2002,
} 
the provider of services needs to have establishment on the territory of the EU, but there is no uniform opinion on the question if the provider of services needs to have the nationality of the EU as well. In favor of the more liberal approach to apply the passive freedom of services even when the provider of services is not a national of a EU Member State, it should be argued that the recipient of a service must not be taken away his rights under EU law just because the service provider with establishment in the EU is not a national of a Member State. ${ }^{16}$ The same argument serves as justification why under the active freedom of services, the nationality of a service recipient with establishment within the EU should be irrelevant.

Within the freedom of services by correspondence it is questionable why the nationality or establishment of the service provider or service recipient should be relevant. The freedom of services by correspondence is here in line with the freedom of goods, which applies equally to third state nationals and EU nationals regardless of their establishment. The only difference is that the goods here are intangible and therefore fall under the freedom of services. On the other hand, while goods cross the border in real world and thereby establish a connection with the territory of the EU, online services have no real and tangible connection to the territory of the EU. Obviously, the EU freedom of services by correspondence should only be applicable if there is a certain connection to the territory of the EU. If we follow the analogy of the active and passive freedom of services, if a provider of services relies on the freedom of services by correspondence he should have establishment on the territory of the EU and if it is the recipient, than the domicile/establishment criteria needs to be fulfilled on his/her side. Until today, there are no CJEU decisions where this question was of relevance. In a digital era it is a crucial question to be answered in order to determine who may rely on the freedom of services by correspondence.

\subsection{Temporariness}

The question arises if the temporariness criteria should also apply to the freedom of services by correspondence. The temporariness referred to in Art 57 (3) TFEU is related to the movement of persons, whereas within the freedom of services by correspondence neither the service provider not the service recipient are moving, but rather only the service itself. Therefore, the temporariness of the service is not

108; Kluth W., in: Calliess Ch.; Ruffert M. (eds.), Das Verfassungsrecht der Europäischen Union mit Europäischer Grundrechtecharta, Kommentar, München 2007, Art. 49/50 EGV, par. 36

16 Pache E., in: Ehlers D. (ed.), Europäische Grundrechte und Grundfreiheiten, Berlin/Boston 2009, p. 372; Randelzhofer, Forsthoff, op.cit., note 8, par. 24 
a requirement under Art 56 and 57 TFEU to apply the freedom of services by correspondence ${ }^{17}$. This is of great importance, because television and radio services, and most digital service are not provided temporarily, but permanently. If the requirement of the service to be provided temporarily would be required for the digital services, the provisions of the TFEU would simply be unfit to liberalize the digital single market. Consequently, a narrow interpretation of the temporariness requirement only to the active and passive freedom of services shall be applied.

\subsection{Competition with other market freedoms}

Within the Digital Single Market strategy, beside the freedom of services, usually the freedom of establishment is considered to be especially important. The freedom of establishment can hardly be in conflict with the freedom of services by correspondence, because the freedom of establishment requires a cross-border movement of a person. ${ }^{18}$ Differently, the freedom of services by correspondence and the freedom of goods can be difficult to distinguish. On the one hand, the freedom of services only encompasses intangible services and thereby has a distinct criteria from the goods. However, if an activity is connected with both tangible and intangible things, the distinction may become difficult. Here the important distinction lies within the answer if the activities are separable or not. ${ }^{19}$

The CJEU decided very early that a data transfer without a durable medium incorporating the digital content, such as television signal, falls within the freedom of services, while the free movement of material, durable medium and other products needed for a television show fall under the freedom of goods. ${ }^{20}$ Therefore, if the activities related to the movement of tangible and intangible things are separable, the movement of tangibles will fall under the freedom of goods, and the movement of intangibles under the freedom of services, If the activities are not separable, a characteristic performance needs to be determined that would make the focus of that activity, and if it is impossible, resort to the application of the rules on solving competition between market freedoms.

\section{THE SECTORAL APPROACH IN THE DIGITAL SINGLE MARKET}

$17 \quad$ Rolshoven, op.cit., note 15, p. 71.

18 Waldheim S., Dienstleistungsfreiheit und Herkunftslandprinzip-Prinzipielle Möglichkeiten und primärrechtliche Grenzen der Liberalisierung eines integrierten europäischen Binnenmarktes für Dienstleistungen, Göttingen 2008, p. 7.

19 Haratsch; Koenig; Pechstein, op. cit. note 8; Randelzhofer; Forsthoff, op.cit. note 8, par. 35

20 CJEU, Giuseppe Sacchi, 155-73, [1974] ECR 409, par. 6 
The digitalization has not contributed to a larger usage of primary EU law on freedom of services by correspondence in the practice of the CJEU. On the contrary, the focus shifted to the secondary law. This approach is not entirely new, because already with the Services Directive of $2006^{21}$ the EU legislator tried to cover most part of the scope of application of the primary law by a directive. The freedom of services by correspondence is, however, not directly regulated by the Services Directive of 2006 and under Art. 2 (2)(c) the electronic communications services and networks, and associated facilities and services are excluded from its scope of application, as well as audiovisual services under Art. 2 (2) (g) of the Services Directive of $2006^{22}$. In addition, within the Digital Single Market the EU legislator took a much more fragmented approach. The Digital Single Market Strategy according to the EU Commission communication is to be based on three pillars:

1. Better access for consumers and businesses to online goods and services across Europe;

2. Creating the right conditions for digital networks and services to flourish; and

3. Maximizing the growth potential of our European Digital Economy. ${ }^{23}$

In each of these pillars the EU has adopted several EU Regulations and/or Directives taking a sectoral approach and fragmenting the freedom of services by correspondence into small pieces. ${ }^{24}$ The most important legislation with the aim to ensure better access for consumer and business to online goods and services include the Geo-Blocking Regulation ${ }^{25}$, Consumer Protection Cooperation Regulation $^{26}$, Digital copyright directive ${ }^{27}$, Digital contracts directives ${ }^{28}$ etc. Under the

${ }^{21}$ Directive 2006/123/EC of the European Parliament and of the Council of 12 December 2006 on services in the internal market, [2006] OJ L 376/36

22 See Bodiroga-Vukobrat N.; Horak H.; Martinović A., Temeljne gospodarske slobode u Europskoj Uniji, Zagreb 2011, p. 228

23. Communication from the Commission, A Digital Single Market Strategy for Europe, COM/2015/0192 final

24 A more comprehensive overview of the secondary legislation within the Digital Single Market Strategy in Samardžić D., Fischer T., European Integration from a Single to a Digital Single Market, Zeitschrift für europarechtliche Studien, Vol. 21, No. 3, 2018, pp. 329-351, 336

25 Regulation (EU) 2018/302 on addressing unjustified geo-blocking and other forms of discrimination based on customers' nationality, place of residence or place of establishment within the internal market [2018] OJ L60I/10.

26 Regulation (EU) 2017/2394 on cooperation between national authorities responsible for the enforcement of consumer protection laws and repealing Regulation [2017] OJ 1345/1

27 Proposal for a Directive on copyright in the Digital Single Market, COM/2016/0593 final - approved by the Council of the EU on 15 April 2019

28 Proposal for a Directive on certain aspects concerning contracts for the supply of digital content, COM/2015/0634 final; Proposal for a Directive on certain aspects concerning contracts for the online 
second pillar of digital networks and services it is the Directive (EU) establishing the European Electronic Communications Code $^{29}$, the amended Audiovisual Media Services Directive ${ }^{30}$, Regulation on Privacy and Electronic Communications ${ }^{31}$ etc. The European Digital Economy of the third pillar shall be maximized with the Free Flow of Non-Personal Data Regulation. ${ }^{32}$

The EU Commission has taken a rather governmental approach by dividing the Digital Single Market into three pillars, which does not correspond to traditional legal fields and disciplines. ${ }^{33}$ The interdisciplinary approach quite significantly ignores also already established concepts of EU internal market law and may be somewhat irritating for a clean legal analysis. In order to conclude to what extent the secondary legislation truly solves problems of the digitalization under the freedom of services by correspondence, the content needs to be put in the perspective of the traditional three step test of the market freedoms: 1 . Scope of application; 2. Discrimination and non-discriminatory measures and 3. Justification.

\subsection{Scope of application}

The Services Directive of 2006 is rather conservative with its scope of application, confirming in its Art 4 that both provider and recipient of services need to have both nationality and establishment in a EU Member State. As already discussed above with regards to the primary law of the EU, for the freedom of services by correspondence such a restriction makes no sense. The Geo-blocking Regulation 2018/302 brings an enormous change and widens the scope of application to all services provided on the territory of the EU, regardless of the nationality or establishment of the provider. As correctly stated in the Recital 17 of the Geo-blocking Regulation: "The effects for customers and on the internal market of discriminatory treatment in connection to transactions relating to the sales of goods or the provision of services within the Union are the same, regardless of whether a trader is established in a Member State or in a third country. Therefore, and with a view

and other distance sales of goods, COM/2015/0635 final

29 Directive (EU) 2018/1972 of the European Parliament and of the Council of 11 December 2018 establishing the European Electronic Communications Code, [2018] OJ L 321/18

30 Directive (EU) 2018/1808 amending Directive 2010/13/EU on the coordination of certain provisions laid down by law, regulation or administrative action in Member States concerning the provision of audiovisual media services (Audiovisual Media Services Directive) [2018] OJ L 303/69

31 Proposal for a Regulation concerning the respect for private life and the protection of personal data in electronic communications and repealing Directive 2002/58/EC (Regulation on Privacy and Electronic Communications), COM/2017/010 final

32 Regulation (EU) 2018/1807 on a framework for the free flow of non-personal data in the European Union, [2018] OJ L 303/59

33 Samardžić; Fischer, op. cit., note 16, p. 346 
to ensuring that competing traders are subject to the same requirements in this regard, this Regulation should apply equally to all traders, including online marketplaces, operating within the Union." Here the EU announces, what should have been clear a decade ago. Services by correspondence are in convergence with the freedom of goods, which applies irrespective of the nationality or establishment of the seller or buyer. When it comes to the other party of the transaction, it arises out of the definition of a customer in Art 2 (12) of the Geo-blocking Regulation $2018 / 302$, which is a term used for the recipient of the service, that an establishment of the customer within the Union is required. A nationality of the customer, however, is not required. Therefore, the Geo-blocking Regulation 2018/302 applies to services provided to any recipient with an establishment within the Union, regardless of the nationality of the service provider or recipient, and regardless if the service provider is established within the Union or not. This is a remarkable improvement in comparison to the Services Directive of 2006, which is in line of the Art 56 and 57 TFEU. This is confirmed in the latest Regulation 2018/1807 on the free flow of non-personal data. It states in its Art 2 (1)(a) that it applies to a service to users residing or having an establishment in the Union, regardless of whether the service provider is established or not in the Union.

When it comes to the cross-border element, it is made clear in the Recital 7 of the Geo-blocking Regulation 2018/302 that it will still be required. Namely, the Regulation does not apply to situations which are purely internal to one Member State where all the relevant elements of the transaction are confined to a single Member State, "in particular the nationality, the place of residence or the place of establishment of the customer or of the trader, the place of execution, the means of payment used in the transaction or the offer, as well as the use of an online interface".

The scope of application of the secondary law within the Digital Single Market confirms that the freedom of services by correspondence does not require temporality as a precondition of its application. It is not required by any of the secondary law within the Digital Single Market.

\subsection{Discrimination and non-discriminatory measures}

The secondary law adopted within the three pillars only prohibits discriminatory measures. Under Art 4 of the Geo-blocking Regulation 2018/302, discrimination based on the nationality, place of residence or place of establishment of the customers are prohibited. ${ }^{34}$ This is the exact definition of the prohibition of direct

34 See Schmidt-Kessen, op.cit., note 9, pp. 561-576 
and indirect discriminatory measures. Such prohibition is naturally far behind the protection granted under the freedom of goods, where the market access criteria from Keck and beyond ${ }^{35}$, encompasses prohibition of non-discriminatory measures related to market access. Already after the case of Italian trailers for motorcycles $^{36}$ and Swedish jet-ski ${ }^{37}$, it was clear that under the freedom of goods it is enough to have a non-discriminatory measure with "a considerable influence on the behavior of consumers, which, in its turn, affects the access of that product to the market of that Member State". This is a much higher level of freedom provided for goods, than currently granted to the digital services under the freedom of services by correspondence. On the other hand, it took the freedom of goods several decades to understand all the ways in which governmental measures take "a considerable influence on the behavior of consumers" and a step-by-step approach cannot be criticized too heavily.

In addition, when examining the content of the secondary law within the first pillar of the Digital Single Market Strategy, it needs to be restated that its named goal of "better access for consumers and businesses to online goods and services across Europe" does not correspond to the legal concept of "market access". Namely, all of the other legal acts except from the Geo-blocking Regulation 2018/302 do not regulate discriminatory or non-discriminatory measures or restrictions of market access but aim to build a solid basis and the legal environment for a future regulation of free access to online services. Or even more generally, many of the secondary law acts do not directly relate to the freedom of services by correspondence, but rather address digitalization in the broadest economic and social context. The development of free access to online services is still in its early phase.

\subsection{Justification}

Although the Digital Market in the EU is very far from its goal to become a Digital Single Market, the fast development of digital services has already raised a lot of concerns within the Member States. Obviously, the threat to privacy and personal data is the number one threat to be mentioned. There not only the CJEU developed a strict necessity test for the restriction of the fundamental right to personal data under Art 8 of the EU Charter of Fundamental Rights (CFR) ${ }^{38}$, but also the

35 Snell J., The notion of market access - a concept or a slogan, Common Market Law Review, Vol. 47, 2010, pp. 437-472, p. 457

36 CJEU, C-110/05, Commission vs. Italy [2009], I-519, par. 57

37 CJEU, C-142/05, Åklagaren vs. Percy Mickelsson and Joakim Roos, [2009], I-4237, par. 26

38 Meškić Z., Samardžić D., The Strict Necessity Test on Data Protection by the CJEU: A Proportionality Test To Face The Challenges at the Beginning of a New Digital Era in the Midst of Security Concerns, Croatian Yearbook of European Law and Policy, Vol. 13, 2017, p. 133-168 
(in)famous GDPR ${ }^{39}$ was adopted. Personal data is therefore in accordance with Art 8 of the CFR a written ground of justification for a restriction of freedom of services by correspondence. The same is true for intellectual property rights, which may serve as a justification ground for the restrictions of the freedom of services. ${ }^{40}$ This has also quite recently been confirmed by the CJEU in the Murphy case on television broadcasting of sports events. ${ }^{41}$ The EU legislator has a narrower legislative discretion in these areas, as restrictions of the free movement of services which are proportional to the goal of personal data protection or intellectual property rights are allowed.

In addition to that, the EU legislator within the three pillars of the Digital Single Market was quite busy codifying grounds of justification. Many secondary law acts relate to consumer protection such as Consumer Protection Cooperation Regulation, Digital Contracts Directive and the Audiovisual Media services Directive. On the other hand, Regulation 2018/1807 on the free flow of non-personal data attempts to ensure the visibility of the distinction between data which does and does not fall within the fundamental right to personal data under Art 8 of the CFR. At the same time, the Regulation 2018/1807 on the free flow of nonpersonal data names public security as the most important ground of justification of a restriction to the freedom of non-personal data and thereby creates a link to the GDPR.

\section{CONCLUSION}

The EU freedom of services by correspondence has the potential to become the most important market freedom in the digital era. The title of the fifth freedom for the Digital Single Market was given by the European Parliament to a secondary legislation on Free Flow on Non-Personal data, which falls within the much broader scope of application of services provided by correspondence. Services provided by correspondence include also free movement of personal data and access to digital services provided cross-border in general. Regardless of the question if

39 Regulation (EU) 2016/679 on the protection of natural persons with regard to the processing of personal data and on the free movement of such data, OJ [2016] L 119/1; See Boban M., Digital single market and EU data protection reform with regard to the processing of personal data as the challenge of the modern world, in: Proceedings of 16th International Scientific Conference ESD 2016, „The legal challenges of modern world, Vol. 1-2 2016, p. 191-201; Škrinjar Vidović M., EU Data Protection Reform: Challenges for Cloud Computing, Croatian Yearbook of European Law and Policy, Vol. 12, 2016, p. 171-207

40 See Schmidt-Kessen op.cit., note 9, p. 561-576, 572

41 CJEU, Football Association Premier League Ltd v. Karen Murphy, Joined Cases C403/08 and C429/08 [2011], I-09083, par. 89 
the title of a new "fifth freedom" may be given to any freedom without changes in the primary law, the name raises a lot of attention and correctly emphasizes the growing importance of the free flow of digital content. From the perspective of the market freedoms, however, personal data as a fundamental right under Art 8 of the EU Charter of Fundamental Rights and the GDPR, are just a ground for justification for the restriction on the market freedoms. They are part of a group of justification grounds such as intellectual property rights, consumer protection and public security as the most important justification grounds in the digital market. Justification grounds do not exclude digital content such as personal data or content related to intellectual property rights from the freedom of services but only justify its restrictions under the conditions of proportionality.

The sectoral approach chosen by the EU under the Digital Single Market Strategy therefore leaves many gaps and lacks a clear system of regulation. On the other hand, the much broader services by correspondence is limited by the conditions set by the TFEU, originally formulated for the active freedom of services. The scope of application of the freedom of services by correspondence in EU primary law is by its wording limited to EU nationals with establishment in the EU under Art 56 and 57 TFEU. Within the freedom of services by correspondence it is questionable why the nationality or establishment of the service provider or service recipient should be relevant. The freedom of services by correspondence is here convergent with the freedom of goods, which applies equally to third state nationals and EU nationals regardless of their establishment. The only difference is that the digital goods in question are intangible and therefore need a certain real-life connection ot the territory of the EU in order for EU law to be applicable .. The Geo-blocking Regulation 2018/302 makes the necessary changes in the right direction, by widening the scope of application to customers with establishment within the EU, regardless of the nationality or establishment of the services provider. This is confirmed in the latest Regulation 2018/1807 on the free flow of non-personal data, which applies to a service to users residing or having an establishment in the Union, regardless of whether the service provider is established or not in the Union. Art 57 (3) TFEU even requires the service to be of temporary nature, which would exclude any permanent digital service from the freedom of services. The CJEU in its jurisprudence never applied the criteria of temporariness to the freedom of services by correspondence and the secondary legislation adopted within the Digital Single Market also did not take it over from Art 57 (3) TFEU. Thereby it implicitly confirms that the temporariness does not apply to freedom of services by correspondence.

While the focus of this analysis is the regulation methodology and its scope of application chosen by the EU legislator, in the future the main question will be if 
the current legislative measures are with regards to the level of protection sufficient to reach the goals of the Digital Single Market. Such development has already been seen with regards to tangible goods within the freedom of goods. The methodology used by the CJEU is far more effective and all-encompassing than the fragmented EU secondary legislation. The newly adopted secondary law within the Digital Single Market still focuses only on discriminatory measures and is far behind the Dassonville, Keck and later jurisprudence on market access applicable not just to the freedom of goods, but also to the most other market freedoms. The Digital Single Market is interdisciplinary, and many acts of its secondary law only address the digital legal environment and some foundations of a digital market but are still far away from abolishing non-discriminatory restrictions of free access to online services. It is a development that took the freedom of goods several decades and the freedom of services by correspondence will need some more time.

\section{REFERENCES}

\section{BOOKS AND ARTICLES}

1. Barnard C., The Substantive Law of the EU-the Four Freedoms, Oxford 2016

2. Boban M., Digital single market and EU data protection reform with regard to the processing of personal data as the challenge of the modern world, in: Proceedings of 16th International Scientific Conference ESD 2016, „The legal challenges of modern world, Vol. 1-2, 2016, p. 191-201

3. Bodiroga-Vukobrat N.; Horak H.; Martinović A., Temeljne gospodarske slobode u Europskoj Uniji, Zagreb 2011

4. Bordaš B., in: Etinski R. et al. (eds.), Osnovi Prava Evropske unije, Novi Sad 2010

5. Gramlich L.; Freier Kapital - und Zahlungsverkehr, in: Pechstein M.; Nowak C.; Häde U. (eds.), Frankfurter Kommentar, Frankfurt 2017, p. 1035-1085

6. Haratsch A.; Koenig Ch.; Pechstein M., Europarecht, Tübingen 2010

7. Holoubek M., in: Schwarze J. (ed.), EU-Kommentar, Baden Baden 2009, Art. $49 / 50$ EGV

8. Kingreen Th., Die Struktur der Grundfreiheiten des Europäischen Gemeinschaftsrechts, Berlin 1999

9. Kluth W., in: Calliess Ch.; Ruffert M. (eds.), Das Verfassungsrecht der Europäischen Union mit Europäischer Grundrechtecharta, Kommentar, München 2007, Art. 49/50 EGV

10. Meškić Z.; Samardžić D., The Strict Necessity Test on Data Protection by the CJEU: A Proportionality Test to Face the Challenges at the Beginning of a New Digital Era in the Midst of Security Concerns, Croatian Yearbook of European Law and Policy, Vol. 13, 2017, p. 133-168

11. Oppermann Th.; Classen C. D.; Nettesheim M., Europarecht, München 2009

12. Pache E., in: Ehlers D. (ed.), Europäische Grundrechte und Grundfreiheiten, Berlin/Boston 2009

13. Randelzhofer A.; Forsthoff U., in: Grabitz E.; Hilf M. (eds.), Das Recht der Europäischen Union-Kommentar, München 2009, Art. 49/50 EGV 
14. Rolshoven M., „Beschränkungen“ des freien Dienstleistungsverkehrs, Berlin 2002

15. Samardžić D.; Fischer T., European Integration from a Single to a Digital Single Market, Zeitschrift für europarechtliche Studien, Vol. 21, No. 3, 2018, p. 329-351

16. Schmidt-Kessen M.J., EU Digital Single Market Strategy, Digital Content and Geo-Blocking: Costs and Benefits Of Partitioning EU's Internal Market, Columbia Journal of European Law, Vol. 24, 2018, p. 561-576

17. Škrinjar Vidović M., EU Data Protection Reform: Challenges for Cloud Computing, Croatian Yearbook of European Law and Policy, Vol. 12, 2016, p. 171-207

18. Snell J., The notion of market access - a concept or a slogan, Common Market Law Review, Vol. 47, 2010, pp. 437-472

19. Trstenjak V.; Beysen E., Das Prinzip der Verhältnismäßigkeit in der Unionsrechtsordnung, Zeitschrift für Europarecht, Vol. 45, 2012, p. 265-284

20. Waldheim S., Dienstleistungsfreiheit und Herkunftslandprinzip-Prinzipielle Möglichkeiten und primärrechtliche Grenzen der Liberalisierung eines integrierten europäischen Binnenmarktes für Dienstleistungen, Göttingen 2008

\section{COURT OF JUSTICE OF THE EUROPEAN UNION}

CJEU, Eugen Schmidberger, Internationale Transporte und Planzüge v. Austria [2003], C-112/00, I-5659, par. 82

CJEU, Commission v. France, C-265/95, [1997], I-6959

CJEU, Graziana Luisi and Giuseppe Carbone v Ministero del Tesoro, Joined cases 286/82 and 26/83, [1984] ECR 377, par. 16

CJEU, Giuseppe Sacchi, 155-73, [1974] ECR 409, par. 6

CJEU, C-110/05, Commission vs. Italy [2009], I-519, par. 57

CJEU, C-142/05, Åklagaren vs. Percy Mickelsson and Joakim Roos, [2009], I-4237, par. 26

CJEU, Football Association Premier League Ltd v. Karen Murphy, Joined Cases C403/08 and C429/08 [2011], I-09083, par. 89

\section{EU LAW}

1. European Commission, Communication from the Commission to the European Parliament, the Council, the European Economic and Social Committee and the Committee of the Regions - A Digital Single Market Strategy for Europe COM(2015) 192 final

2. Regulation (EU) $2018 / 1807$ on a framework for the free flow of non-personal data in the European Union, [2018] OJ L 303/59

3. Directive 2006/123/EC of the European Parliament and of the Council of 12 December 2006 on services in the internal market, [2006] OJ L 376/36

4. Regulation (EU) $2018 / 302$ on addressing unjustified geo-blocking and other forms of discrimination based on customers' nationality, place of residence or place of establishment within the internal market [2018] OJ L60I/10

5. Regulation (EU) 2017/2394 on cooperation between national authorities responsible for the enforcement of consumer protection laws and repealing Regulation [2017] OJ 1 345/1 
6. Proposal for a Directive on copyright in the Digital Single Market, COM/2016/0593 final - approved by the Council of the EU on 15 April 2019

7. Proposal for a Directive on certain aspects concerning contracts for the supply of digital content, COM/2015/0634 final; Proposal for a Directive on certain aspects concerning contracts for the online and other distance sales of goods, COM/2015/0635 final

8. Directive (EU) 2018/1972 of the European Parliament and of the Council of 11 December 2018 establishing the European Electronic Communications Code, [2018] OJ L 321/18

9. Directive (EU) 2018/1808 amending Directive 2010/13/EU on the coordination of certain provisions laid down by law, regulation or administrative action in Member States concerning the provision of audiovisual media services (Audiovisual Media Services Directive) [2018] OJ L 303/69

10. Proposal for a Regulation concerning the respect for private life and the protection of personal data in electronic communications and repealing Directive 2002/58/EC (Regulation on Privacy and Electronic Communications), COM/2017/010 final

11. Regulation (EU) $2018 / 1807$ on a framework for the free flow of non-personal data in the European Union, [2018] OJ L 303/59

12. Regulation (EU) $2016 / 679$ on the protection of natural persons with regard to the processing of personal data and on the free movement of such data, OJ [2016] L 119/1

\section{WEBSITE REFERENCES}

1. European Parliament, "Free flow of non-personal data: Parliament approves EU's fifth freedom”, [http://www.europarl.europa.eu/news/en/press-room/20180926IPR14403/freeflow-of-non-personal-data-parliament-approves-eu-s-fifth-freedom] Accessed 11.05.2019 